\title{
Preliminary Studies on some Ethno-botanically important Non Timber Forest produces (NTFPs) in Jamboni Block of Paschim Medinipur District of West Bengal.
}

\author{
Pampi Ghosh \\ Angiospermic Taxonomy and Ethnobotany Laboratory of Botany \\ Seva Bharati Mahavidyalaya, Kapgari, Paschim Medinipur, West Bengal, India
}

\begin{abstract}
The paper deals with 25 major ethno-botanically important Non Timber Forest Produces (NTFPs) of South West Bengal forest at Jamboni community development block (JCDB). It reflects source and sink relation of the products in the said forest ecosystem. It also broadcasts the proper conservation measures of plant species. The products of plants includegreen leaves, fruits, twigs, unwanted timber as fuel, litter, brumes, fiber and flosses, sticks, barks from roots and stems, seeds, basket making stem, medicinal plants, plant material for local use like mushrooms, kendu fruits, baichi, tasar, lac, kurkut(eggs of red ant) etc. for different purposes. All the products are seasonally collected from forests by local people of the said area but most of the ethnic groups use these products luxuriantly to earn money from market for their own need. For the collection of minor forest produces, forest department have no rigidity thereby. Collectors of JCDB may be the inhabitants of the area or under the group as members of Forest Protection Committees (FPCs). The local markets are the nodal area for the sale of the products where they can sale freely and easily, and buyers can purchase these NTFPs for the big markets to earn maximum profit in later stage. By and large, they collect huge amount of NTFPs from the forest which need conservation to protect the species from the loss of abundance of species and to protect it in near future either locally or by scientific way.
\end{abstract}

Keywords: Jamboni Block, NTFPs, Ethnobotany, Marketing, Sustainable management.

\section{Introduction}

Ethnobotany is concerned with ethnic people and plant relationship. As a whole the people of ethnic type of forested area use plants and plant related products for their daily livelihood from natural forest to degraded stand which have great ecological significance (Das, 2007). According to Jain (2012) the soul of ethnobotany is primarily and intrinsically the knowledge of the indigenous/local people acquired through oral tradition or personal observations and experience about plants of their own region. Therefore, the study of ethnobotany from the past to presentmakes avenues of path-breaking research in the subject like Botany and its future is infinite. It is likewise the work of Ethnobotany of SantalPargana published by Botanical Survey of India (Goel, et al., 1984).The study area fall under Jamboni Block of PaschimMedinipurDistrict of West Bengal State which is mainly lateritic area filled with dry deciduous natural and degraded sal (Shorea robusta Gaertn. f.) vegetation. Other dominant plants in ecological series in the said area are Cleistanthus (Parasi) and Croton (Kamala). Here, plants are mainly deciduous and vegetation is under coppice sal along with piyal (Buchanania lanzan Spreng. ), Rakta Rahara (Soymida febrifusa Adr. Juss.) and Mahul (Madhuca indica J. F. Gmel.). The plants cover entire the area with 2-3 layers canopy along with some epiphytes and parasites. Gradually the lower layer is filled with shrubby vegetation and the ground cove is filled with small patches of herbs but mostly the ground is barren where the pattern of the parent material is red Murom andbolder (red lateritic PAN formation) type. Plantation stands cover Eucalyptus and Acacias (Acacia auriculoformis and A. mangium) in a large scale with no ground cover except a few dense patches of Chromolaena and Lantana as exotic alien species. These two alien species are fuel wood producing one for the people where no boundaries of forest department to fell the plants round the year. In some sites of social forestry area they collect litter from forest and degraded land of village where they planted Anacrdium occidentale (Cashew) and Ailanthus excelsa in a large scale. Some sites of the village they planted Mahogany (Swietenia spp.) and Lamboo (Dysoxylum sp.) for quality wood production but the NTFPs produced they are the seeds which is used in nursery of public as well as in departmental type. So, there is a large scope of NTFPs production by seeds which are potentially important. During monsoon, some ephemeral plants grow there but the abundance is very low. Creepers like Asparagus racemosus, Ipomoea hastata, Ichnocarpus frutescens, Hemidesmus indicus, and Smilax ovalifolia grow there with moderately high frequency but do not spread heavily by the propagation due to less deposition of organic matter even high erosion by annual water runoff during monsoon. So, pattern is mainly heterogeneoustype where dominant and co-dominants are species like Shorea robusta (Seddlings to saplings), Anogeissus latifolia, Madhuca indica, Buchanaina lanzan, Zizyphus mauritiana, Gardenia latifolia, Semecarpus anacardium, 
Terminalia bellerica, T. chebula, Polyalthia cerasoides, Haldinia cordifolia, Ailanthus excela, Oroxylum indicum etc. Shrubby vegetationcomposition is dominated by Cleistanthus collinus, Mimusa rubricaulis, Meyna laxiflora, Gardenia resinifera, Gardenia gummifera, Combretum decundrum and Flacourtia ramontchii. Herbaceous vegetation elements are dominated by Atylosia scarabeoides, Evolvulus nummularius, Sessiolepis sp., Aristida adcendeonoides, Aristolochia indica, Ochna perpussilla, Dicliptera bupleuroides, Ageratum conyzoides, Vernonia cinerera, etc. Some woody climbers found here are Ampelocissus latifolia, Dalbergia scandens, Bauhinia vahlii, Butea suberosa, Hemidesmus indicus, Celastrus paniculatus, Combretum decundrum, Butea spathacea, Ichnocarpus frutescens, Tiliacora racemosa etc. Leafless parasites like Cuscuta and Cassytha are also available in the deep forest and margin of the forest with low intensity. Some plants grow near the forests which are planted by forest department as avenue. These grow better along the roadside as avenue and ornamental therefore people become more interested to grow them. These are Tabebuia roseoalba (white trumpet tree), T. impetiginosa (pink trumpet tree), T. serratifolia (Yellow trumpet tree), Delonix regia, Peltophorum ferruginosum and Caesalpinia pulcherrima etc. Plants are the main source of fuel wood, litters, medicine, food and vegetables, cushion, pillows, ropes, fibers, tooth brush, shelter, fodder for domesticated animals, and for aesthetic purpose. Primary occupation of the villagers is cultivation of rice in a small land nearbyforest. Other works they performare as wage labour, small business, service and collection of different NTFPs from forest for direct use or indirectly to earn moneyfrom market. Therefore, forest is the main source of livelihood of the ethnic and non-ethnic villagers.Some ethnic people are engaged in hunting and collection of green sal leaves as well as twigs from the forest for their income generation. They collect mushroom during post monsoon from forest and from river side jungles (Dulung River) and sale these in local market. The locally available mushrooms found here are Parab chatu, putka chatu, wee chatu, sal chatu. Other people involved in basket making and making of earthen pots and similar articles to develop economy of their family. For the burning of earthen articles they need huge amount of fuel wood which comes from forest. All the varied types of fuel are coming from forest except straw of rice from paddy field which is costly and is used by local farmer for their cattle feed and thatching. So, largely they depend on forests. Therefore, use pattern and dynamics of NTFPs in the said area is very important for ethnic people which may be the objectives of further research from different branches of Science and humanities. By and large, all the people are interdependent and they have to conserve the forests and forested animals for their eco-sustenance. Therefore, Forest Protection Committees have been made to manage the forests in a sustainable way. But, for the betterment of the societies' need, more and more research on the said branch is essential i.e. either this satisfy the need of the people's urgency or not, therefore students and researchers would be engaged in research and development to the forth cominggeneration to generate ethno-botanyknowledge. The empiric knowledge of the said area in a better form is required which may not be ethnobotany but it must be a botany of varied field like Economic botany of the said area. According to the concept of Jain (2012) explore the path with the words, "Ethnobotany-good, bad and path-breaking!". This is because rapid socio-economic changes in rural India make Ethnobotany dynamic (Jain 2005), and its future multifaceted applications and directions have been projected (Jain, 2010). Therefore a critical evaluation of more and more plants are to be required to justify the statement in near future though this example of 25 plants of NTFPs in ethnic area is not enough to quantify the sustenance of species and people of the said area. This a step of first research in this area for the sustenance of life for more backward people of red lateritic forest of south West Bengal in our country like India.

\section{Study Area}

The area is fall under Jhargram Sub-division of PaschimMedinipur District of West Bengal State. The total area is 326.60 square kilometer (Wikipedia, $12^{\text {th }}$ June 2013 at 20:14 last modified). Headquarter of this block is at Gidhni and located at $22^{\circ} 27^{\prime} 04^{\prime \prime} \mathrm{N}$ and $86^{\circ} 52^{\prime} 44^{\prime \prime}$ E. The block having panchyat samities like Chinchira, Chilkigarh, Dharsa, Dhubri, Gidni, Jamboni, Kapgari, Kenddangri, Parihati. Number of Villages under this block is more, but the study area includes 22 villages of Jamboni Block under PaschimMedinipur District, West Bengal of India.Three sites in each village have been selected randomly. These are called natural forest, degraded stand and plantation stand. These are taken for the study to record the floristic composition seasonally available including different activities on NTFPs going on. Not only the villages taken for study, had the other areas studied for the samemarkets. Binpur weekly market, daily market of Binpur, Dahijuri, Parihati, Gidhni, Chilkigarh, Jhargram, Jamboni, Chinchraand Fekoghatare taken for the study of source and sink relation of NTFPs which are botanically valuable but ethno-botanically important. The vegetation along the river vegetation of dulung was taken for the study. Riverbank vegetation was selected because, river dulung flows from Kanaisore hill forest area under Chotanagpur Plateau of Jharkhand state and carrying a large number of propagules time to time. So, propagules of varied types blowing along the flow of river water round the year. Therefore basin of river during summer was also taken for study. Some house hold study was also taken for consideration for the daily activities of people of the said area which are ethnic and non-ethnic type. Maximum villages studied for the establishment of source and sink relation of NTFPs were Alampur, Barbhum, Chilki, 
Gopalpur, Hatisuli, Jugibandh, Kenduasuli, Kuchasuli, Rakhalmara, Bank ber, Banksol, Chinchra, Chilkigarh, Dumria, Jambani, Kanimahuli, kapgari, Khatkhura, Parihati, Parulia, Gidhni, sangram etc. Among the study sites villages like Kanimahuli, Khatkhura, Chinchra, Dumuria etc. were the border villages of East Singhbhum District of Jharkhand state (Previously under the state Bihar). These villages have been studied better to study the edge effect of species with ecotonal character. So, total area studied was $8.02 \%$ under different communities of the block under Jhargram Sub-division. The dominant tribal group under study was Santhal, which is distributed heterogeneously in the study area since time immoral. The water bodies found there are varied but some ponds having permanent vegetation due to characteristic features of wet land in the said area. No studies on such vegetation have been made but their output and flow of important NTFPs studies have also been recorded. These are eggs, fishes, water lily, snails, some aroids, Sagittaria, aligator weeds, water hyacinth (Eichornia) and water lettuce.

\section{Objectives Of Study}

NTFPs are the products of plants and animals of the forest area and are the forest fringe village products either in degraded land or plantation sites. Small patches of water bodies were also found here and there which grow small amount of aquatic products which have quality importance. But from botanical point of view this has a vast economic and ecological significance. Therefore to run the smooth life style and to develop economy of rural people, proper management is required to enhance the sustenance of products as well as economy. So, following points are to be studied in near future and therefore the present study includes-

1. To study the vegetation pattern of Jamboni Community Development Block.

2. To study how the underlying pattern of Ecosystem performs the function in ethnic and non-ethnic area.

3. To study the types of vegetation, i.e. natural, degraded and plantation stand of vegetation and the seasonal flow of some NTFPs.

4. To study the flow of NTFPs as source and sink and the management by the people.

5. Role of forest departments and NGOs to develop sustenance for economy of the people.

6. Study of illegal collection of plants, and prepare a linear line to understand its impact on vegetation in forest.

7. To prepare Parallel guideline to grow vegetation better and management of resource with some examples.

8. To study major NTFPs of the said area and identify the nodal markets for the sale of the products.

\section{Material And Methods}

Several ethno botanical surveys were done in the forest fringe villages of Jamboni block, under Jhargram Subdivision of Paschim Medinipur District. Primary and secondary types of data were collected from field and from literature as refernces. The study is the preplanned field work as per the project of ethnobotany of Jamboni Block, submitted to UGC, ERO, Kolkata for permission and financial assistance. The plan of work was sketched in connection with the source and sink of ethnobotanically important NTFPs available in the regions. The major tribes studied were the Santal, Bhumij, Kheria, Sabar, Lodha, etc. including some non tribal communities for cross studies regarding plants of ethnobotanical importance as because the villages are heterogeneous. Plants are listed alphabetically along with the ethnic names and the typical products as NTFPs. Field collections like plant specimens, NTFPs of some plant parts, photographs and soils including roots were collected seasonally to study more and conserve them for further study. All the materials were preserved in Herbarium and museum section of Botany, Seva Bharati Mahavidyalaya, Kapgari, PaschimMedinipur, West Bengal, affiliated to Vidyasagar University. Roots of some plants were also collected from field and preserved in FAA solution. Dry parts of the fruits, seeds, barks and roots were preserved in a jar/container with naphthalene balls. Some photographs were kept in a Removable Hard Disk (RHD), and some are under process for publication. Underground parts were preserved in a $4 \%$ formalin solution. Tribal informants of field workers were taken for consideration to develop idea in near future. Identification was done with the help of standard literature (Duthie, 1960; Hooker 1892-1897, Haines,1921-1925 ;Jain \&Mudgal 1999, Prain, 1963; Das, 2007, Anonymous, 1997, 2005, 2010).The names of plants were cross checked and finally placed following Bennet (1987). The ethnobotanical parameters were selected as per the literature of Jain and Mudgal (1999). NTFPs and the other valuable products were studied following the work of Malhotra et al., (1991). Knowledge from some buyers of forest fringe market was also taken for the study. To study the plant specimens, museum and herbarium section of CAL Herb was used before presenting the document. Herbarium and museum specimens were prepared as per the methodology of Jain and Rao (1977). For medicinal uses of plants different books of Govt. have been used but for general consideration the common book used was Kirtikar and Basu (1918). Some scattered literature used to study the Social aspects (Malhotra et al., 1991, Roy et al., 2000). Presentation of plants for different aspects was placed as per the literature of Jain and Mudgal, 1999. 


\section{Results And Discussion}

The present investigation reports 25 important non timber forest produces (NTFPs) of the said area with great ethnic use directly or indirectly. These are having market demand and therefore income generation and flow of money is also concerned with the source and sink of the products. All NTFPs are produced from forest land, degraded stand and wasteland of the area, excepting all these, some grasses are much more important because these are also used for making brooms and fishing articles. These are collected and transported in local markets. So, rural ethnic people generate money from these products. Therefore, conservation and sustenance of the habitat as well as species is very much essential before going to study them. Following are some of the products of natural forests as well as degraded one/plantation stand along with vivid ethnic importance.

1. Adhatoda vasica Nees (Vasak, it is used in common cold and in whooping cough), 2. Agave americana Linn. (Kongra, is a common plant used to frame living fence in village boundary, it is also used to prepare cord)., 3. Andrographis paniculata (Burm.f.)Wall.exNees (Whole plant is medicinal and applied in amoebic dysentery and used as tonic, also marketed.), 4. Aristida adscensionis L. (Kharang : Used to make brooms, also marketed), 5. Bauhinia variegata Linn. (Kuralsak-used as vegetable, also marketed), 6.Buchanania lanzanSpreng.(Piyal, Kernel used for making quality sweets and also used for Skin beautification), 7.CaryaarboreaRoxb.(Kumbhi, the bark is used to make the local cord), 8. Combretum decundrum Roxb.(Atang/Antur-basket making species which is highly demandable at Binpur, Chilkigarh and in the local daily market at Dahijuri, Jhargram with higher frequency of distribution)., 9. Diospyros Roxb. (Ripe fruits are marketed as Kendule which is edible/Leaves are called biripata.), 10. Diospyros sylvatica Roxb.(local name Bisgab, fruits/whole plant used as fish stupefying agent), 11. Elephantopus scaber Linn.(locally called Hatikan, roots used to prepare Bakharboti a tablet which is used to ferment local beer-Haria), 12. Flacourtia indica(Burm. f.) Merr.(Fruits is edible and Ban boichi twigs are used to treat the round worm), 13. Adina cordifolia (Roxb.)Hook.f. ex Bran. (Karam-used in festival/worshipped as god), 14. Hewtia bicolor (Vahl) Wt. Arn.(Bon Pui, used as vegetables), 15. Holarrhena pubescensWall.Ex G. Don.(Kurchi-Seeds, bark of stem is used in dysentery.), 16. Ichnocarpus frutescens $\mathrm{R}$. Br. (Moderately frequent species need immediate departmental protection because this species is used to make fisherman's basket and exported for unknown use outside the area which need immediate market survey), 17. Madhuca indica J. F. Gmel.(Mahul-Flowers are used to prepare local wine and marketed as local NTFP), 18. Oroxylum indicum Vent. (Sonapata: the fruits and seeds are marketed for their ornamental value which is used by the artists to make fancy doll with the help of Bamboo.), 19. Phoenix acaulis Roxb.(Leaves of Stem-less date palm used for making broom), 20. P. sylvestris Roxb.(Leaves used in a large scale for sale outside the area, which need immediate protection), 21. Rhinacanthus communis Nees.(Juipana-The whole plant is medicinal, the present report revealed that the leaves have anticancerousproperties. Roots used in snake bite. Performance of the species is available in the said area with Low frequency), 22. Shorea robusrta Gaertn.f. (Green sal leaves, twigs, litter as dry leaves, dry branches, seeds, etc. are used for different purposes.Species available with highest frequency), 23.Terminalia chebula Retz.(Hartuki fruits are used to treat stomach problem and are marketed seasonally), 24. Woodfordia fruticosa Kurz (Abata the dry flowers is used in Dasakarma Bhandar), 25. Zizyphus mauritiana (Burm. f.)Wight.\&Arn.(Kul-which is used as laxative), (See Photo Plates)

VI. Figures In Photoplates (1-3)

Plate 1

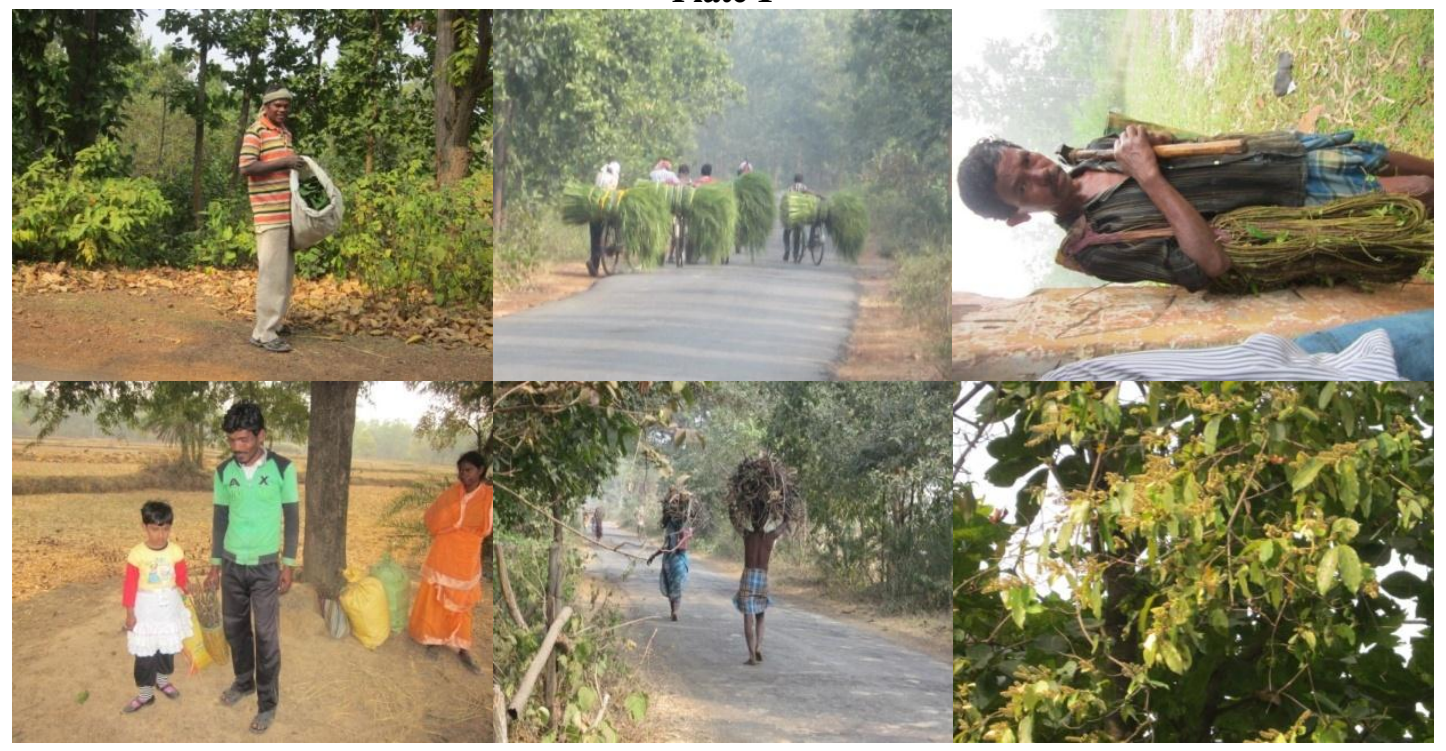




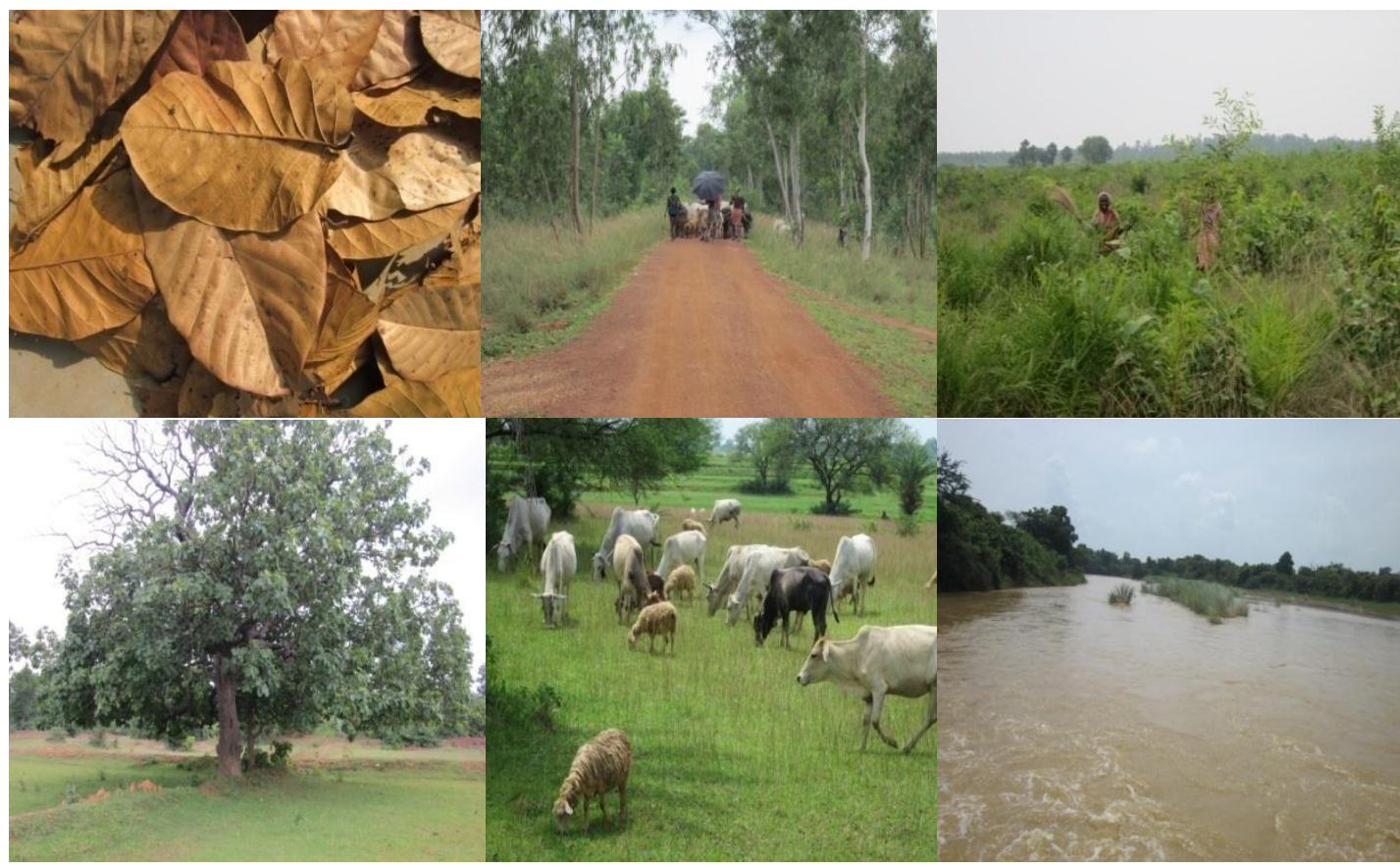

Fig. 1 Plucked green leaves of Shorea robusta; Fig. 2 Carrying green leaves of Stem-less date palm (Phoenix acaulis); Fig. 3 Exploiting Ichnocarpus frutescens stem by uprooting plants; Fig. 4 Tooth brush collected from young shoot of Shorea robusta; Fig. 5 carrying dry twigs as fuel; Fig. 6 Green flowering scape of Combretum decundrum (Atang) used for making basket; Fig. 7 Dry leaf of sal (Shorea robusta) used as fuel of tribal people; Fig. 8 Plantation stands of Eucalyptus sp. with fodder plants used for Grazers and browsers along with marginal grassland; Fig. 9 Women collecting Aristida sp. (Kharang) for brooms; Fig. 10 Mahul tree (Madhuca indica) near sal forest; Fig. 11 Grazed Cattle of grassland in a tribal village; Fig 12 Rich vegetation at the River banks of Dulung. (Figures from top left to right and similar in way as $1,2,3, \ldots 4,56$, $. .7,8,9$..In such a way, by author herself)

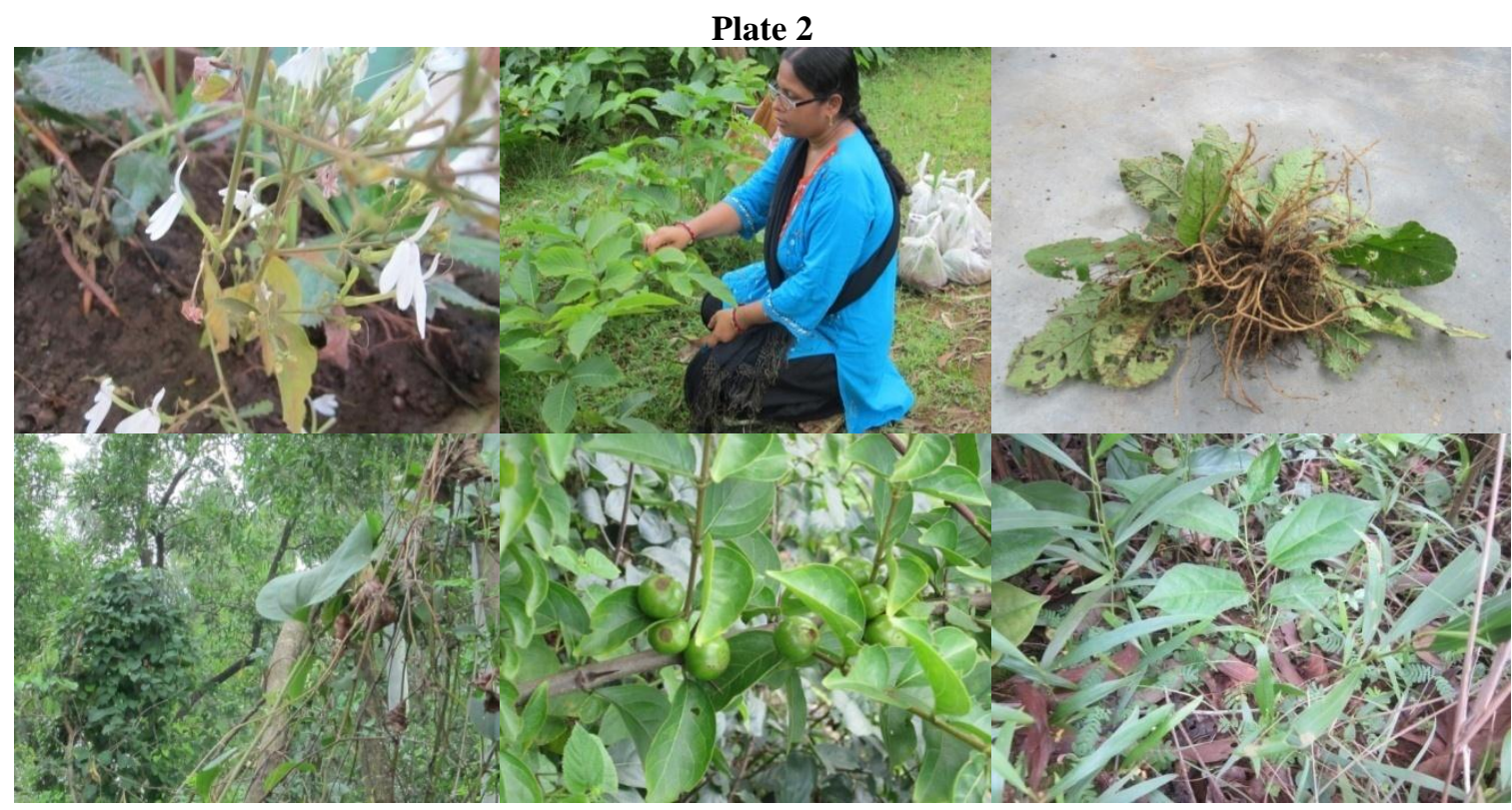




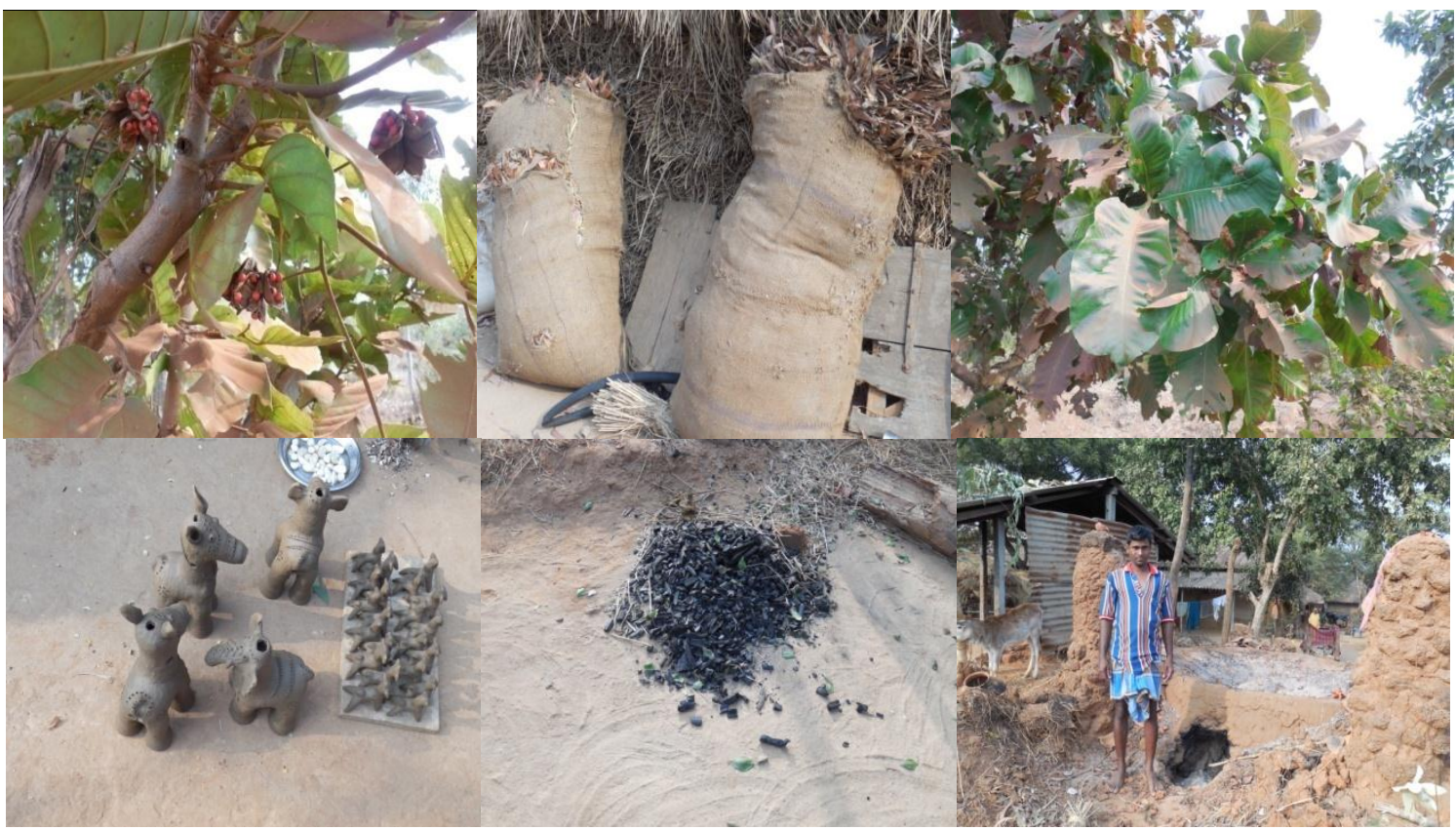

Fig. 13 Habitat of Important medicinal plant Rhinacanthus sp. of Acanthaceae now a day's used in cancer research; Fig. 14 Author collecting bark and soil around Holarrhena pubescens; Fig. 15 Roots of Hatikan (Elephantopus scaber) as an important marketed NTFP available in forest; Fig. 16 Ramdantoon- as woody climber of forest; Fig. 17 Mainakanta/Mainaphal fruit (Vangueria spinosa) during monsoon; Fig 18. Aristolochia indica (Isarmul/Hansalata)-an important medicinal plant; Fig. 19 Abrus precatorius fruits (Kunchphal), Fig. 20 Dry leaf litter of Acacia mangium and A. auriculoformis; 21.Kumbhi-Careya arborea of Lecythidaceae used to make cord from stem bark; Fig. 22 Earthen tattoo prepared by non-ethnic people (Kumar) for worship or for offering prayer at Jaherthan/Gram Goran (Sacred grove); Fig. 23 Charcoal of sal wood prepared by ethnic, that to be used by Blacksmith in a village; Fig. 24 Special Furnace (Chula) used to burn earthen pots, toys etc. before selling in a market.

\section{Photo Plate 3}

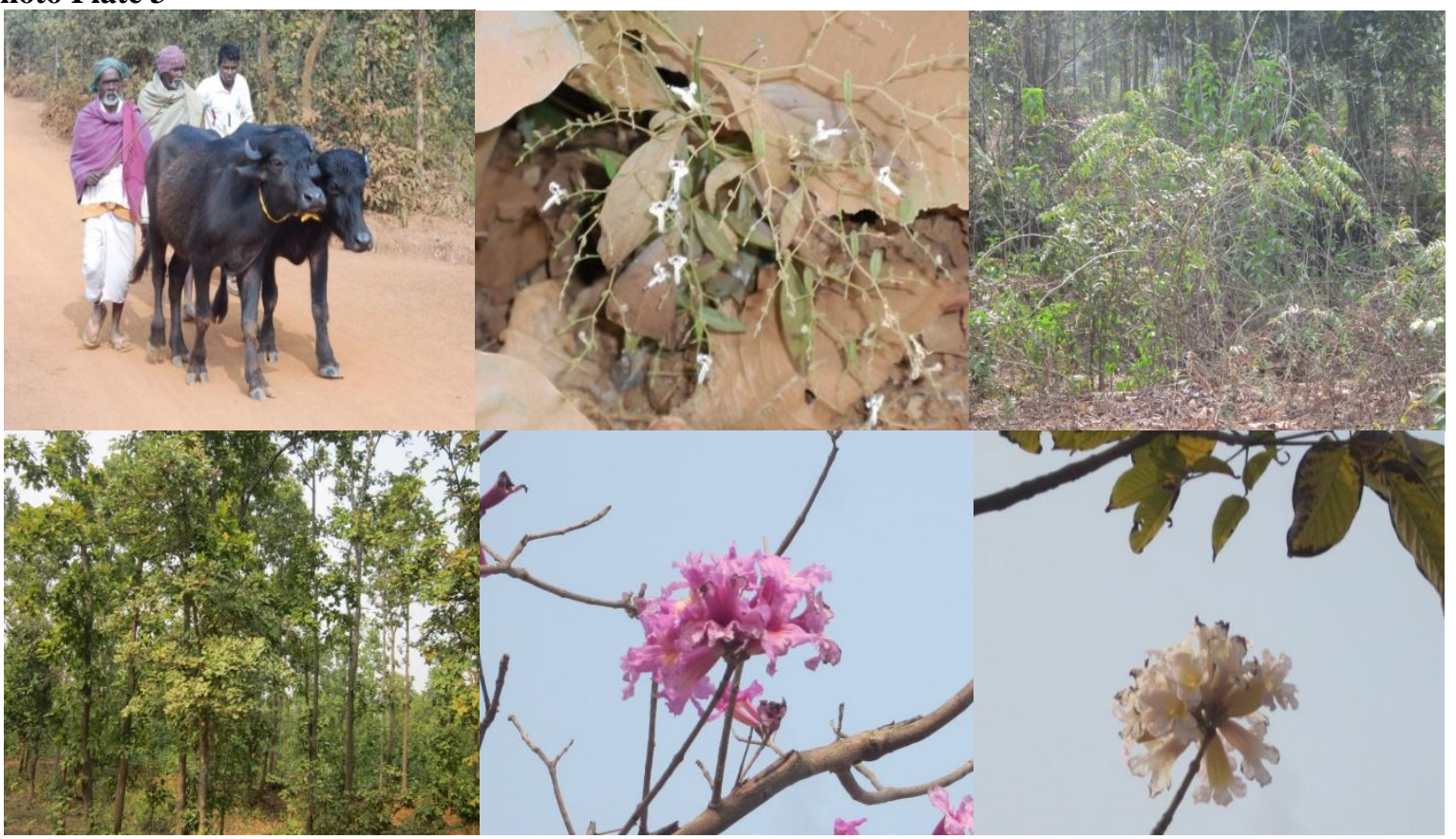




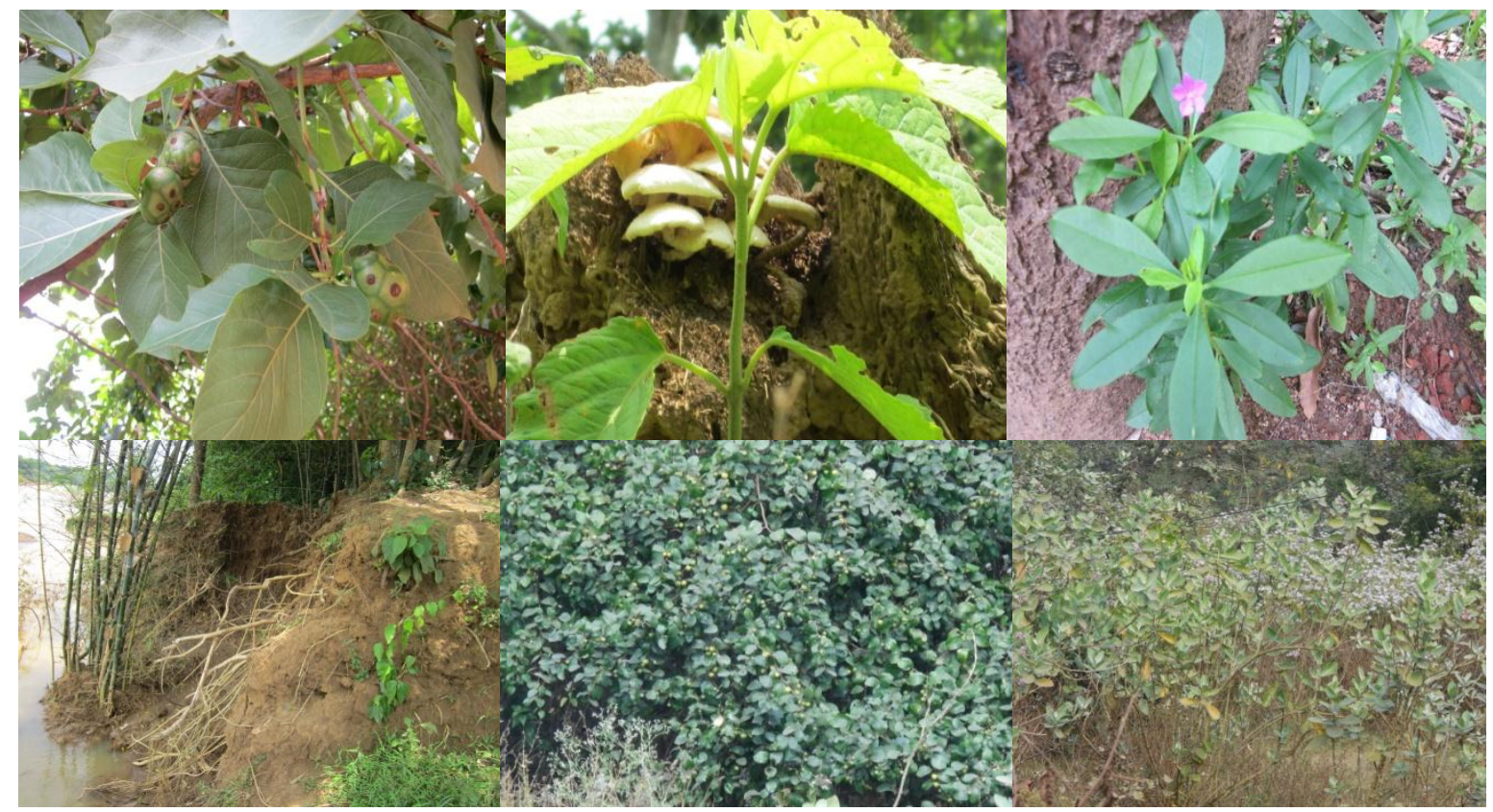

Fig. 25 Buffaloes of a village before selling at market, a people using sal twigs as stick; Fig. 26 Flowering scape of Andrographis paniculata (Kalmegh); Fig. 27 Woodfordia fruticosa bush; Fig. 28 Dry deciduous coppice sal Vegetation; Fig. 29 Tabebuia impetiginosa (pink trumpet tree), as ornamentyal one ; Fig. 30 Tabebuia roseo alba (white trumpet tree); Fig. 31 Fruits of Morinda citrifolia; Fig. 32 Mushroom of wild kind.; Fig. 33 Talinum portulacifolium -AlakPui ; Fig. 34 Tiliacora racemosa and bamboos (Bambusa sp.) near river bank; Fig. 35 Zizyphus jujuba fruits ; Fig. 36 Calotropis procera and Chromolaena odorata (Exotic species). [All the photographs/figures were taken from field of Jamboni Block, Jhargram, PaschimMedinipur, W.B. by author.]

\section{Summary Of The Findings}

All the plants are useful but some are more useful and having good market value to develop local economy. Therefore, for sustenance of market demand, proper scientific management is required round the year. Therefore to grow plants better, all the plants in a forest regular monitoring is essentials by local people. Keeping the concept in mind they should be well trained to floe the material in a substantial way with the help of specialists either from forest Department or from NGOs accustomed with Forest Management (FM) and policy maker in our country. But, in fact all the ideas need special attention to follow up rules mandatory for all in the area. In this site, immediate measures should be required to protect the plant species like Ichnocarpus frutescens (Linn.) R. Br. (Kalilat) and Forest Protection Committees (FPCs) should be more active to protect the species which is destroying from illegal collection. Immediate but second category protection is required for Phoenix acaulis Roxb. (Stem-less date palm) and P. sylvestris Roxb. (Date palm) which are being exploited without any management. $3^{\text {rd }}$ category protection is required to conserve the litters. For ground species like mushrooms, grasses, medicinally important herbs, and properfield based management is required to check the unauthorized collections. Seasonally all the litters are being decomposed by decomposers which ultimately produce organic matter of the jungle and nourishes plants immediately after the germination of seeds to establish advent growth. Therefore, Forest Department (FD) and FPCs should take care about the problem of the said area as early as possible. During monsoon forest fringe people should encourage to grow and take care of Kalmegh and Vasak plants vigorously. They should collect the plants during late November when the plants generate mature seeds. To overcome the problem, and conserve the diversity of species regular monitoring as well as campaign in local area through governmental sector is needed. So, local management through cutting of exotic alien species likes Lantana camara and Eupatorium odoratum Linn. (Chromolaena odorata (Linn.) King \& Robin. ) should be encouraged by local people for the fuel wood (as NTFP) which may enhance the growth of the local vegetation in near future. 


\section{Acknowledgements}

The author is thankful to the authority, UGC, Eastern Regional Office, Kolkata, WB for financial support. The author also acknowledges the persons of the local area for their help as and when required. Last but not least thank is due to the permission and support taken from the Institutional head of SBM, Kapgari, Paschim Medinipur. Thank is also to the departmental staff for their technical support.

\section{Journal Papers:}

\section{References}

[1] Ghosh, P. Studies on some ethno-botanically important plants of Jhargram Block, West Midnapore, West Benngal, Indian J. Applied \& Pure Bio. 27(2), 2012, 195-197.

[2] Jain S K. Dynamics of Traditional Knowledge, Indian J. Trad. Knowledge, 4(2), 2005, 115-117.

[3] Jain, S K. Ethnobotany in India: some thought on future work, Ethnobotany, 22, 2010, 1-4.

[4] Jain, S K. Ethnobotany-Good, bad and Path-breaking! Ethnobotany, 24 (1\&2), 2012, 1-3

[5] Roy S B. Bilateral Matching Institution: An illustration in Forest Conservation, The Journal of Indian Anthropological Society of India, 27, 1992, 253-262.

[6] Roy, S B; Mukhopadhyay, D and Das, S. Strengthening Institutions in Joint Forest Management systemic Approach to Forest Conservation, Social Science, New Delhi, 2001.

[7] Sahoo, A K and Goel, A K. Ethnobotanical Studies in Odisha (1942-2011); in pursuit of plant Conservation, Ethnobotany, 24 (1\&2), 2012, 29-42.

Books:

[8] Anonymous. Flora of West Bengal, Vol.-1,1997, Flora of India, Series-2, BSI, Kolkata.

[9] Anonymous.Participatory vegetation Monitoring: Concept, Practice and Experiences, IBRAD repot article by S B Roy and S Dey, Web article downloaded, pp.1-6 on 21.12.2013.

[10] Anonymous. Medicinal Plant Resources of South West Bengal, Vol.-I, 2005, Research Wing, Directorate of Forests, Govt. of W.B.

[11] Anonymous. Medicinal Plant Resources of South West Bengal, Vol.-II, 2010, Research Wing, Directorate of Forests, Govt. of W.B.

[12] Bennet, S S R. Name changes in Flowering Plants of India and Adjoining Regions, TriseasPublishers, 1987, Dehra Dun.

[13] Duthie, J F. Flora of Upper Gangetic plains, Vol. I, II, 1960, Botanical Survey of India, Calcutta.

[14] Goel, A K; Sahoo, A K and Mudgal, V. A contribution to the Ethnobotany of SantalPargana, BSI, Howrah, 1984, Printed by Deep Printers, Ramesh Nagar, New Delhi.

[15] Haines, H H. The Botany of Bihar and Orissa, Vol. I-IV,(1921-1925), BSI, Calcutta.

[16] Hooker, J D. Flora of British India, Vol. 1-7, (1892-1897), BSI, Calcutta.

[17] Jain, S K and Rao, R. R. A Hand book of Field Herbarium Methods, Oxford and IBH Publishing Company, 1977, New Delhi.

[18] Jain, S K. and Mudgal, V. A Hand book of Ethnobotany, Bishen Singh and Mahendra Pal Singh, 1999, Dehradun.

[19] Kirtikar, K R and Basu B D. Indian Medicinal Plants, I-IV, International Book Distributors, 1918, Dehra Dun.

[20] Malhotra K C; Deb, D; Dutta, N; Vasulu T S, Yadav G and Adhikari, M. Role of Non-Timber Forest Produce in village Economy: A Household survey in Jamboni Range, MidnaporeDistrtict, West Bengal. IBRAD, 1991, Calcutta.

[21] Prain, D. Bengal Plants (Vol-I , II), Bishen Singh and MahendraPal Singh, 1963, Dehradun.Revised Edn, BSI, Kolkata

[22] Roy S B; Mahapatra, T and Yadav, G. Forest Protection and management by communities in Midnapore District, West Bengal Published in the Book "Joint Forest Management and Community Forestry in India-An Ecological and Institutional Assessment" Edited by N H Ravindranath, K S Murali and K C Malhotra, Oxford IBH Pub. Co. Pvt. Ltd.,2000.

Thesis:

[23] Das, D. 2007. Vegetation Ecology of Forests of Southwest Bengal with special reference to Non-Timber Forest Produce (NTFPs) Productivity, Ph.D Thesis, awarded the degree from Vidyasagar University, Midnapore, West Bengal (from CNH, BSI worker, Kolkata). 